\title{
Non-Human Animal Trauma During the Pandemic
}

\section{Victoria O'Sullivan ${ }^{1}$}

Published online: 16 June 2020

(C) Springer Nature Switzerland AG 2020

Keywords Covid-19 $\cdot$ Non-human animals · Virus $\cdot$ Pandemic $\cdot$ Meat industry $\cdot$ Animal experimentation $\cdot$ Veganism

\section{Introduction}

This piece of writing is an activist gesture intended to counter the invisibility of animal trauma in the context of the SARS-CoV-2 virus, which has been traced to a type of 'wet market' where live animals, including pangolins, wolf pups, hare, snakes, racoon dogs, porcupines, pigs, chickens and peacocks, are slaughtered on order (Dalton 2020a). For years, animal welfare organisations have worked tirelessly to increase societal knowledge of the cruelty of these markets and the threats to human health that they pose (such is our anthropocentrism that animal advocacy organisations must also often foreground human concerns). Their calls have gone unheeded - animal trauma largely invisible. Hence, when a pandemic emerges, it may not register as incongruous when a popular New Zealand psychologist writes a Facebook post that is shared thousands of times (and made into a newspaper article) suggesting 'sharing funny videos of cats pushing stuff off shelves, and dogs falling asleep in chairs in human-like poses' as a way to alleviate Covid-19-related anxiety (Latta 2020). Why do we use the companionability of animals when we want to, yet turn a blind eye to their torment? Why do we find the footage of sheep playing on a carousel in a deserted playground so joyful, yet line up to eat them the very second a lockdown level is lifted?

Similar markets, such as Chatuchak Market in Bangkok, which was 'raided' after a documentary produced for 60 Minutes Australia suggested that it was a 'ticking timebomb' for another zoonotic disease, have been touted as tourist attractions (Harvey, Hannaford, and Clancy 2020). Chatuchak Market ranks number three on TripAdvisor's list of top tourist attractions in the city, and travel writers promote the market and its fighting Siamese fish and chickens (Stephens n.d.). Whilst reports concerning the raid say that 'the animals were seized and their safety assured', it is difficult to track down

Victoria O'Sullivan

v.osullivan@auckland.ac.nz 
any further information (Taylor 2020). Similarly, as noted by Wang et al. (2020), after China's legislature banned the eating of 'wildlife' after the virus emerged, there has been a lack of information concerning the fate of the hundreds of animals intensively bred on the farms that are said to service the wet market industry.

A history of animal trauma is not only present at the site where the virus emerged, but the consequences (or 'spillover' effects) of the pandemic on non-human animals are myriad. I experience them as overwhelming and difficult to keep track of. A couple of times, after taking a 24-hour break from tracking this damage, I have sat down at my computer only to discover a new event or matrix of events. A story about a dog that died after being hurled from a tower block one morning at 4 a.m. and landing on the sunroof of a car was 2 months old by the time I accidentally stumbled across it (New Zealand Herald 2020). This incident was the outcome of a local media outlet 'tweaking' the words of a scientist who had appeared on a national television network. Instead of saying that cats and dogs who had been in contact with suspected patients should be quarantined, it was instead reported that they could spread the virus. Our tolerance for the unthoughtful, rash modification of information has clearly become quite high when something that yields such dire consequences is referred to so underwhelmingly as 'tweaking'. It is also the case that stories concerning animal trauma often foreground human interest. After detailing the violence of this event (how the blood stained the pavement and how the sound was like a tyre exploding), we are given the trivial detail that the car owner is waiting for details of the dog's 'owner', so they can file an insurance claim.

In writing this, I imagine myself as an insect with compound eyes, observing and documenting but fragments of a much larger picture. These 'fragments' are the spillover effects impacting animals who have been 'exposed' to humans in such a way that their short lives have taken place on a laboratory or farm.

\section{Spillover Effects}

There have been many news stories about the fact that the virus emerged in a wet market, and novelty stories (sometimes fake) of animals 'reclaiming' or 'taking over' space recently vacated by humans have appeared (sometimes in the 'lifestyles' section of newspapers). Goats roaming a village in Wales, sheep playing on a deserted children's playground and dolphins and swans swimming in Venetian canals that now run clear are events that propel images so familiar that they feel banal to write about. Stories of animals in zoos getting on just fine, without the gaze of humans, have also emerged (Binning 2020). However, reports of struggling zoos drawing up lists of which animals to slaughter first, in the event they must feed animals to each other, and reserving polar bears, icons of the climate emergency, until last, have also appeared (Schuetze 2020). In another instance, an aquarium in Tokyo asks people to FaceTime their spotted garden eels who are 'missing' humans so much that in just a brief period, they have become 'shy' and bury under the sand when staff walk by (Elliot 2020). The fact that a respite from the human gaze may have prompted the eels to register just how overexposed they are to it - installed as they are in a small tank that affords $360^{\circ}$ views whilst humans listen to elevator-style music, as if they are in a hotel lobby-is not considered.

But there continue to be a myriad of other spillover effects impacting non-human animals. These types of effects are much less visible than the cute 'reclaiming of space' 
and 'secret lives of zoo animals' stories, certainly do not go viral and require focused effort to locate in the first place. Spillover effects impacting non-human animals are radically present in the current moment, in all their fleshy materiality, but also long range in character.

\section{Animals in Laboratories}

On March 14, an article with the hubristic title, 'These Lab Animals will Help Fight Coronavirus', was published in The New York Times (Gorman 2020). Its author pondered what animals would be 'used' to test virus susceptibility and develop a vaccine. Transgenic mice bred from sperm and embryos of the hACE2 strain of mouse that was developed in 2003 with susceptibility to SARS and 'kept on ice' lest another (zoonotic) pandemic emerged were suggested, as were ferrets, hamsters and monkeys. A few days after this article was published, another appeared on a vegan 'lifestyles' website dangerously declaring the 'fact' that a Covid-19 vaccine will not be tested on animals (Enjoli 2020). But in fact, research using animals to facilitate vaccine development had already taken place.

Research into the susceptibility of ferrets, ducks, pigs, chickens, cats and dogs (or rather kittens and puppies) was published less than 4 weeks after these articles. The purpose of Shi and colleagues' research was to identify an animal 'test model' for vaccine development and to find out if the virus could spread to other animals that might then become reservoirs (2020). Amongst the animals experimented on were five 'beagle dogs'. At just 3 months old, their lives would have been conceived just 2 months before the virus first made its presence felt - the puppies knew no other life but that which was entangled with it. 'Seven subadult cats' (6-9 months old) and an 'unquantified number of juveniles' (70-100 days old) were also used (the words 'kittens' and 'puppies' are not used in the text of the paper nor its title, which would read altogether differently if they were).

Ironically, it is because we share our lives with such species and presumably love them that these 'companions' were used-Shi et al. write 'cats and dogs are in close contact with humans, and therefore it is important to understand their susceptibility [to the virus]'-however, dogs, of course, serve many roles that place them in 'close contact' with humans that are not predicated on love and companionship (2020: 2 ). Speaking to our toxic relationship with animals and why qualities such as 'companionability' and 'pliability' render particular species and breeds vulnerable to being used as experimental subjects, the authors note that 'it was difficult to perform regular nasal wash collection on the subadult cats because they were aggressive. To avoid possible injury, we only collected faeces from these cats and checked for viral RNA in their organs after euthanasia' (2020: 2).

In a rare moment, during one of Prime Minister Jacinda Ardern's daily Covid-19 updates, non-human animals and 'care' were drawn together in the same sentiment when Dr. Ashley Bloomfield (Director General of Health) updated the public on an amended health act order now applicable under a less restrictive level: 'People can travel to care for their pets and other animals because we know it's important to look after these important members of our households' (2020 emphasis added). Later, in response to a concern presented by a journalist - that because of New Zealand's success in stamping out the virus, the country might be placed at the 'back of the 
queue' if a vaccine is developed overseas-Bloomfield mentioned that 90-100 trials were underway around the world and that the government is keen on an Australia New Zealand Army Corps (ANZAC) approach to contributing to the development of a vaccine. Embedded in those few words, 'x amount of trials underway', are possibly hundreds of animal lives. The inadvertent war analogy is interesting, but not because of the way in which the virus has generated discursive practices that pitch countries against each other (that has come in the form of threats to purchase vaccines for exclusive use) but because there is a different type of 'war' going on —one that Dinesh Wadiwel (2015) might say is waged against animals. One has to wonder what sort of trials these are and if animals are being used. Embedded in the brief timeframe of this particular update are some of the seemingly invisible toxic contradictions we hold concerning animals.

\section{Animals on Farms}

Generations of farm animals subjected to the outcome of the normalisation of nonvegan diets due to the opportunistic inculcation of a captive audience of American school children in lockdown represent a longer range spillover effect. Mere weeks before the virus resulted in the shuttering of slaughterhouses and meatpacking facilities in the USA, illness and death of workers and the culling of millions of farm animals due to a 'slaughter backlog', the website of the American Dairy Association North East published links to videos of farm tours, targeted at various age groups (ADANE 2020). In the video for children 4-9 years of age, a farmer tells us that the cows behind him are on 'vacation' because they are not presently part of the milking herd and that every single one is pregnant. Absent is any reference to what will happen to their calves, many of whom will be deemed surplus to requirements and slaughtered when they are just a few days old-like those born in New Zealand due to recent consumer stockpiling of milk, which has been so extreme that it has ameliorated reduced demand from the hospitality industry and produced higher profit margins for dairy giant Fonterra (Espiner 2020). Nor is there any reference to the toxicity of the meat/dairy industry in general - its animal slaughter, pollution of environment, contribution to climate change and indifference to its disposable workforce. But in the context of Covid-19, the necropolitics of the meat industry, as it pertains to animals and sometimes to humans, has never been clearer.

Strangely synchronous is the fact that the site where the virus emerged is one where animals are exploited for human consumption, and now in the USA, slaughterhouses and meatpacking facilities, where workers are unable to observe social distancing, have surpassed 'long-term care' facilities as the primary site of infection. Introduced amid the pandemic by the US Department of Agriculture, after many years of lobbying by meatpacking companies, 'line speed waivers', which allow plants to exceed limits on how many animals can be 'processed' (killed) per minute and 'guarantee that workers [will be even] more crowded along a meatpacking line', have rendered social distancing even harder (UFCW 2020).

By April 28, when an executive order classifying meat plants as 'critical infrastructure' was passed by the Trump administration (meaning that they must remain open), more than 5000 meat- and food-processing workers had shown symptoms of the virus, and twenty had died (UFCW 2020). Annie Grant, an employee of Tyson (the world's 
second largest meat processor), died after being pressured to return to work after becoming ill so that she could help 'feed America' - a variation of the Trump administration's nationalistic propaganda that food supply workers 'step up' to 'serve' America (Jordan and Dickerson 2020). Twenty-two meatpacking facilities had also closed, including a plant in South Dakota owned by Smithfield (another meat industry giant), which closed in mid-April after more than 800 workers contracted the virus, making it possibly the largest single-source coronavirus 'hotspot' in the USA (Sternlicht 2020). The executive order was made in response to lobbying by meatpacking companies and farmers not wanting to lose profit margins by continuing to feed and house 'perfectly slaughterable' animals.

Slaughterhouse shutdowns have interrupted supply chains and led to farmers culling at least two million animals (Kevany 2020). On the same day that the executive order was made, The National Pork Board published the webinar 'COVID-19: Animal Welfare Tools for Pork Producers' (2020). It lists ways to 'euthanise' animals, including gunshot, electrocution, carbon dioxide and manual blunt force trauma (a 'preferred' method), 'ventilation shutdown plus' (a 'permitted under constrained circumstances' method, which involves closing inlets to barns/sheds and turning off fans so that body heat raises the temperature until animals eventually die from hyperthermia, whilst 'plus' means adding carbon dioxide or turning up the heat), and finally-it seems that any method goes - nothing is listed under 'not recommended'.

Seizing a narrative that is indifferent to the welfare of animals, and that of workers, popular media in the USA presents the break in the 'food supply chain' (or the possibility that people might be forced to take a break from eating meat) as a 'national emergency' and 'terrifying' (CNBC 2020).

\section{Scenarios that Provide Hope (Albeit Sometimes in the Negative)}

Donna Haraway (2016: 44) argues that the 'intrusion of Gaia' - the 'feedback' that emerges from the violence we unleash - is an 'event that undoes thinking as usual', whilst novelist Arundhati Roy (2020) describes the pandemic as a rupturing event that forces us to think differently. So what might reimagining our relationship with nonhuman animals involve? The three scenarios below point to some hopeful possibilities.

\section{The Longevity of Exposure that Is the Shuttering of Meatpacking Facilities in the USA}

The pandemic, a product of the violence that humans have unleashed on other species, has resulted in yet further instances and modes of violence and has forced into visibility existing exploitative practices (of animals and also humans). Our practices are so parasitic that in the context of Covid-19, it is becoming increasingly impossible not to notice the many ways in which animals are exploited and how they are forced to prop up a broken, necropolitical and capitalist system (the fact that people can surely not fail to notice, provides some hope, albeit in negative terms).

So, whilst some spillover effects have not been very visible or sustained as an issue in the public eye, the shuttering of slaughterhouses and meatpacking facilities in the USA has been. This 'longer exposure' seems to be due to fears concerning food supply chains and profit margins, as much as it is about the illness and death of workers. 
During this time, news stories sympathetic to farm animal trauma have appeared in The Guardian (Kevany 2020) and the National Review (Scully 2020) as well as nonmainstream media (e.g. Scott-Reid 2020) though most reporting does not pick up on the animal welfare issues (e.g. Ruane 2020).

\section{A Discursive Shift}

In New Zealand, the potential landfilling of millions of dollars' worth of meat because independent butchers were deemed a 'non-essential' service better fulfilled by supermarkets over the lockdown period might give us pause to consider the word 'essential' in relation to the meat industry (Martin 2020). Whilst the landfilling poignantly points to the futility that was/is the slaughter of farm animals, it might give us pause to consider whether their systematic exploitation, including forced insemination and separation from their newborns (who are then slaughtered) is really so? Whilst this scenario does not represent an actual change for animals, perhaps it represents a discursive shift?

\section{The Presence of Practices of 'Care and Concern' that May Not Be Visible at First Glance}

In a short article titled 'COVID-19 Drives New Threats to Bats in China', drawing on local news stories, Zhao (2020) notes that hibernating bats in or near homes have been removed and released into wild areas that are not their natural habitat, posing threats to their survival, and suggestions of indiscriminate mass slaughter have been made. A short news article, in turn, refers to Zhao's article to provide evidence that bats are being 'destroyed', giving the impression that this is happening without any dissent from any source (Dalton 2020b).

However, the two news stories that Zhao refers to reveal more nuanced information than what is able to be captured in the short form of his article. One refers to a policeman capturing a bat in a small cotton quilt, and a compelling image of the unusual scene of a policeman dressed in personal protective equipment and holding the quilt in such a way to facilitate the bat's exit into the wintery surrounding forest is included-indicating care for the bat, if perhaps not the best course of action (Ying 2020). At least one response to the article, written by an online reader, urges people to treat the bats with respect and not cause them harm due to misplaced fears.

The author of the second article writes 'in the past few decades, almost every fatal disease from bats has been accompanied by human active invasion of this species', urges people to remain calm and quotes at length a researcher at the School of Life Sciences at Fudan University and a member of the Shanghai Nature Reserve Expert Committee who is sympathetic to the dilemma faced by bats (Shanghai News 2020). However, none of these details - the policeman's attempt to treat the bat respectfully (as palpable in the image of him with the bat), the wider discursive life of the news article (reader-response indicating dissent to the practice of removing the bats) and the orientation of the second article, which is sympathetic to the plight of bats-comes through in Zhao's article.

Like effective management of the virus, which needs careful 'contact tracing' (a process of working backwards to identify persons that may have come into [in-]direct 
contact with an infected person), a careful tracing backwards of material events, and discursive practices, is also needed (but perhaps too, a practice of 'looking closer' at the visual image is needed, to help reimagine, or rather reimage, our relationship with nonhuman animals). This 'careful tracing' is needed because the circulation of insubstantial, incorrect or 'tweaked' information can produce catastrophic consequences for animals, including death (e.g. New Zealand Herald 2020) and potential exposure to experimentation because the public is prompted to believe that such practices will not occur (e.g. Enjoli 2020).

A practice of careful tracing might help locate practices of care and concern - the existence of which could be amplified. It might also operate in a way that is counter to some of the information practices that have emerged in the context of the pandemic.

\section{Conclusion}

More purposeful than the change that might eventually come about because of the first two scenarios discussed above is an ecology of practices that might facilitate reimagining our relationship with non-human animals. Right now, it is as if we need a collaborative project that involves moving as a singular body, but with compound eyes, bearing witness, recording and carefully tracing the myriad instances of animal trauma that are emerging - an activist project of mourning that is ethical and political. The sheer multiplicity of these events, seen together, might 'force thinking differently' or 'undo thinking as usual'.

We might also question how language allows us to maintain exploitative and capitalist practices that locates the problem 'somewhere else' (specifically 'wild' and 'wildlife' are curious terms to describe animals born and bred in an intensive farming system and are terms that may preclude us from considering the ethics of other farming practices that have also produced zoonotic diseases). In New Zealand, the virus has given rise to the word 'non-essential' being used in the context of the meat industry-I wonder how this 'accident of discursive circumstance' could be used to question our dependency on meat?

We might also place under the spotlight everyday 'micro-practices' that reinscribe human exceptionalism and the invisibility of animal trauma, albeit sometimes inadvertently, such as the writing of seemingly harmless Facebook posts (e.g. Latta 2020) and their corresponding 'liking' and 'sharing' (sometimes to the point of virality). Perhaps, we like/share such posts because they are made by those we have come to celebrate most in society, by those we desperately look to, to provide solutions to problems we desperately want to be fixed (e.g. What do I do with my bored teenager during lockdown? How do we stop the virus from gaining a foothold here?). A social media practice and way of thinking palpable in New Zealand during the pandemic has involved rash suggestions that we knight and make dames of those we feel have solved the problem of the virus gaining traction on these shores and create new national holidays in their name (though we are a country still reeling from the trauma of colonisation).

Though not to diminish such achievements, this 'solving' is a surface effect, for it is a solution to a human health problem that has emerged out of the bigger problem of how we exploit non-human animals and, in the specific context of Covid-19, what has 
emerged out of a collection of practices that include the acquisition, breeding and finally slaughter of non-human animals for, and at, wet markets. In addition to the obvious animal suffering that these practices produce, they also present risks to human health - something that animal welfare organisations have also been at pains to alert us to. We might amplify the voices and practices of these organisations instead, or at least as well as, and find heroes in organisations and collectives as much as in individualsto decentre, for a moment, the individual human.

Noticing and amplifying (micro-)practices that make a positive difference to nonhuman animals, as present in the third scenario discussed, might resist the logic of certain reporting practices that have emerged during the pandemic, which, when their subject matter is non-human animals, have involved the production of quickly generated, incomplete or rashly modified information, resulting in dire consequences for animals.

\section{References}

ADANE. (2020). Virtual farm tours while you're stuck at home. American Dairy Association North East, 15 March. https://www.americandairy.com/news-and-events/dairy-diary/dairy-farming/virtual-farm-tourswhile-youre-stuck-at-home.stml. Accessed 18 March 2020.

Binning, E. (2020). COVID-19 coronavirus: Auckland Zoo: What's it like for the animals during Covid-19 lockdown? The New Zealand Herald, 2 May. https://www.nzherald.co.nz/nz/news/article.cfm?c_id=1 \&objectid=12328694. Accessed 2 May 2020.

Bloomfield, A. (2020). COVID-19 updates. The Beehive, 30 April. https://www.beehive.govt. nz/feature/covid-19-updates. Accessed 15 May 2020.

CNBC. (2020). Trump expected to use DPA to keep meat processors open. Consumer News and Business Channel, 28 April. https://www.cnbc.com/2020/04/28/trump-says-will-sign-order-on-virus-relatedliability-problems.html. Accessed 19 May 2020.

Dalton, J. (2020a). From coronavirus to antibiotics: the ways we use animals "still risks spreading disease." The Independent, 18 March. https:/www.independent.co.uk/news/health/coronavirus-antibiotics-wildanimals-wildlife-china-wuhan-bat-pangolin-a9407261.html. Accessed 1 May 2020.

Dalton, J. (2020b). Coronavirus: exterminating bats blamed for spreading COVID-19 would increase risk of further diseases, warn experts. The Independent, 20 April. https://www.independent.co. uk/environment/coronavirus-bats-china-pangolin-colony-wildlife-kill-pandemic-covid-19-a9469551. html. Accessed 1 May 2020.

Elliot, J. K. (2020). Lonely eels need video calls so they don't "forget" humans during coronavirus. Global News, 1 May. https://globalnews.ca/news/6892746/coronavirus-eels-facetime-call/. Accessed 1 May 2020.

Enjoli, A. (2020). The coronavirus vaccine won't be tested on animals. Live Kindly, 17 March. https://www. livekindly.co/coronavirus-vaccine-wont-be-tested-animals/. Accessed 1 May 2020.

Espiner, G. (2020). Fonterra seeing demand spike for some products. Radio New Zealand, 31 March. https://www.rnz.co.nz/news/business/413073/fonterra-seeing-demand-spike-for-some-products. Accessed 1 May 2020.

Gorman, J. (2020, March 14). These lab animals will help fight coronavirus. The New York Times, 14 March. https://www.nytimes.com/2020/03/14/science/animals-coronavirus-vaccine.html. Accessed 1 May 2020.

Haraway, D. (2016). Staying with the trouble: making kin in the Chthulucene. Durham: Duke University Press.

Harvey, G., Hannaford, T., \& Clancy, N. (2020). World of pain [Television documentary]. https://www. youtube.com/watch?v=Y7nZ4mw4mXw. Accessed 1 May 2020.

Jordan, M., \& Dickerson, C. (2020). Poultry worker's death highlights spread of coronavirus in meat plants. The New York Times, 9 April. https://www.nytimes.com/2020/04/09/us/coronavirus-chicken-meatprocessing-plants-immigrants.html?searchResultPosition=5. Accessed 1 May 2020. 
Kevany, S. (2020). Millions of farm animals culled as US food supply chain chokes up. The Guardian, 29 April. https:/www.theguardian.com/environment/2020/apr/29/millions-of-farm-animals-culled-as-usfood-supply-chain-chokes-up-coronavirus. Accessed 1 May 2020.

Latta, N. (2020). Coronavirus: keep calm, wash your hands, and don't hoard supplies. Stuff, 18 March. https:/www.stuff.co.nz/national/health/coronavirus/120369747/coronavirus-keep-calm-wash-yourhands-and-dont-hoard-supplies. Accessed 1 May 2020.

Martin, R. (2020). Millions of dollars worth of meat headed to landfill due to trading ban. Radio New Zealand, 31 March. https:/www.rnz.co.nz/news/national/413077/millions-of-dollars-worth-of-meat-headed-tolandfill-due-to-trading-ban. Accessed 1 May 2020.

New Zealand Herald. (2020). "Dogs and cats reportedly thrown from apartments" in China over coronavirus fears. New Zealand Herald, 1 February. https:/www.nzherald.co.nz/world/news/article.cfm?c_id=2 \&objectid=12305201. Accessed 3 April.

Roy, A. (2020). The pandemic is a portal. Financial Times, 4 April. https://www.ft.com/content/10d8f5e8-74 eb-11ea-95fe-fcd274e920ca. Accessed 1 May 2020.

Ruane, M. E. (2020). Two million Delmarva chickens euthanised as virus hobbles processing. The Washington Post, 25 April. https://www.washingtonpost.com/local/two-million-delmarva-chickenseuthanized-as-virus-hobbles-processing/2020/04/24/82fc93a4-865d-11ea-878a-86477a724bdb_story. html. Accessed 1 May 2020.

Schuetze, C. F. (2020). Zoo may feed animals to animals as funds dry up in pandemic. The New York Times, 15 April. https://www.nytimes.com/2020/04/15/world/europe/germany-zoo-coronavirus.html. Accessed 1 May 2020.

Scott-Reid, J. (2020). Farmed animals culled en masse as COVID-19 outbreaks halt meat and dairy production. Sentient Media, 29 April. https://sentientmedia.org/farmed-animals-culled-en-mass-ascovid-19-outbreaks-halt-meat-and-dairy-production/. Accessed 1 May 2020.

Scully, M. (2020). The human cost of "culling" livestock and "depopulating” farms. The National Review, 7 May. https://www.nationalreview.com/2020/05/coronavirus-pandemic-human-cost-of-culling-livestockdepopulating-farms/. Accessed 1 May 2020.

Shanghai News. (2020). Shanghai residents call wildlife conservation department to expel bats around their houses. Shanghai News, 8 February. https://sh.qq.com/a/20200208/014581.htm. Accessed 13 May.

Shi, J., Wen, Z., Zhong, G., Yang, H., Wang, C., Huang, et al. (2020). Susceptibility of ferrets, cats, dogs, and other domesticated animals to SARS-coronavirus 2. Science, eabb7015. https://doi.org/10.1126/science. abb7015.

Stephens, H. (n.d.). Plan your trip: Chatuchak weekend market. Hurry, hurry. Thai Airways. https://www. thaiairways.com/plan-your-trip/destinations/en/wtf-388.htm. Accessed 19 May 2020.

Sternlicht, A. (2020). South Dakota Gov. Kristi Noem wants to reopen Smithfield foods plant 'in a matter of days'. Forbes, 27 April. https://www.forbes.com/sites/alexandrasternlicht/2020/04/27/south-dakota-govkristi-noem-wants-to-reopen-smithfield-foods-plant-in-a-matter-of-days/\#89c2fae4384e. Accessed 1 May 2020.

Taylor, S. (2020). Thai police raid illegal "wildlife market" after 60 minutes exposé. Nine Now, 26 April. https://9now.nine.com.au/60-minutes/illegal-wildlife-wet-market-update-raided-and-shut-down-by-thaiauthorities/cf0fc0ea-9805-4805-a983-cbba4237b299. Accessed 1 May 2020.

The National Pork Board. (2020). COVID-19 webinar: animal welfare tools for pork producers. The Pork Checkoff, 28 April. https:/www.pork.org/public-health/what-you-need-to-know-about-covid-19/porkindustry-covid-19-webinars/. Accessed 1 May 2020.

UFCW. (2020). Trump order to keep meatpacking plants open must include immediate action to strengthen coronavirus testing and safety measures. United Food and Commercial Workers International Union, 28 April. http://www.ufcw.org/2020/04/28/order/. Accessed 19 May 2020.

Wadiwel, D. J. (2015). The war against animals. Leiden: Brill.

Wang, H., Shao, J., Luo, X., Chuai, Z., Xu, S., Geng, M., \& Gao, Z. (2020). Wildlife consumption ban is insufficient. Science, 367(6485), 1435. https://doi.org/10.1126/science.abb6463.

Ying, S. (2020). Beijing residents call police to remove bats from their houses. 11 February. https://wxn.qq. $\mathrm{com} / \mathrm{cmsid} / 20200211 \mathrm{~A} 06 \mathrm{BJG} 00$. Accessed 1 May 2020.

Zhao, H. (2020). COVID-19 drives new threat to bats in China. Science, 367(6485), 1436-141436. https://doi. org/10.1126/science.abb3088. 